\title{
A significant study on EGFR mutations in lung carcinomas
}

\author{
Yugandhar Pothina ${ }^{1}$, GudeliVahini ${ }^{2 *}$, M.lalitha Shree ${ }^{2}$, Thota Asha ${ }^{2}$ \\ ${ }^{1}$ Department OfPulmonology, Asram Medical College, Elluru, West Godavari District, Andhra Pradesh, India \\ ${ }^{2}$ Department Of Pathology,Asram Medical College, Elluru, West Godavari District, Andhra Pradesh, India
}

\begin{abstract}
Background: Lung cancer is one of the leading causes of cancer related deaths among both men and women. Non-small cell lung carcinomas comprises the majority (about 75\%) of lung cancers, has proven difficult to treat due to poorly understood pathological mechanism. Recent advances in cell signalling pathways that control cell survival have identified genetic and regulatory aberrations that suppress cell death, promote cell division and induce tumorogenesis. One such discovery is that of epidermal growth factor receptor. Overexpression of EGFR has been reported and implicated in pathogenesis of many human malignancies including Non- small cell carcinoma of lung.
\end{abstract}

Aims And Objectives; To study EGFR expression by immunohistochemistry in diagnosed cases of Non- small cell carcinomas of lung at our institute.

To determine the value of EGFR test by IHC in predicting response to targeted therapy and clinical outcome.

Materials and Methods: A retrospective and prospective study of bronchial biopsies diagnosed as Non-small cell carcinomafor a duration of two yearswith their expression to EGFR immunohistochemistry marker at our institute and these patients response to the targeted therapy.

Results: Out of twenty nine(29) cases of lung malignancies majority were Non -small cell carcinomas- twenty seven cases (27), of which adenocarcinomas were seventeen (17) cases topped the list, followed by squamous cell carcinomas (5) cases, malignant epithelial lesions (3) cases and poorly differentiated carcinomas(2) cases. Small cell carcinomas were two (2) cases. Fifteen cases of non-small cell carcinomas cases showed EGFR mutations and twelve patients were started on the targeted therapy of Gefitinib and Erlonitib. All twelve of them showed good response to chemotherapy.

Conclusions: Most of the Non-small cell carcinomas of lung have EGFR mutations especially all adenocarcinomas in non-smokers. The clinical outcome of patients could be predicted. There is significant response to targeted chemotherapy.

\section{Keywords: Lung, Cancer, Epidermal, Growth, Factor.}

\section{Introduction}

Lung cancer is one of the leading causes of cancer related deaths among both men and women. ${ }^{(1)}$ Non-small cell lung carcinomas comprising the majority (about $75 \%$ ) of lung cancers, have proven difficult to treat due to poorly understood pathological mechanism. ${ }^{(2,3)}$ Recent advances in cell signaling pathways that control cell survival have identified genetic and regulatory aberrations that suppress cell death, promote cell division and induce tumorogenesis. One such discovery is that of epidermal growth factor receptor. EGFR is a transmembrane receptor tyrosine kinase protein expressed in normal epithelial, mesenchymal and neurogenic tissue. EGFR over expression is related to cancer proliferation and has been implicated in pathogenesis of many human malignancies including Non -small cell carcinoma of lung. ${ }^{(4,5)}$ Gefitinib is the first molecular target agent for lung cancer which inhibits tyrosine kinase of the epidermal growth factor receptor. Erlotinib provides survival benefit in a phase III trial for chemotherapy for Non-small cell lung carcinomas. Studies identified somatic mutations in EGFR gene around the region encoding the ATP-binding pocket of the receptor's tyrosine kinase domain which increases sensitivity of tumour cells to gefitinib. ${ }^{(6,7)}$

\section{Aims and Objectives}

To study EGFR expression by immunohistochemistry in diagnosed cases of Non -small cell carcinomas of lung at our institute.

To determine the value of EGFR test in predicting response to targeted therapy and clinical outcome

\section{Materials and Methods}

A retrospective and prospective study of lung biopsies diagnosed as Non- small cell carcinomas in two years 
(2017-2018) period with their expression to EGFR - IHC marker at our institute and those with positive expression, their response to the targeted therapy.

The patients were followed post therapy for a duration of ten years. The response to therapy was assessed in retrospective cases based on patients' condition and disease free survival gained. Clinical characteristics and treatment details were collected from the patient's medical records.

\section{Results}

Out of twenty nine (29) cases of lung malignancies majority were non-small cell carcinomas (27) -93\% and small cell carcinomas were two (2) cases- 7\%. (FIG:1) Out of (27) non-small cell carcinomas there were seventeen (17) adenocarcinomas - $63 \%$ which topped the list, followed by squamous cell carcinomas (5) 18\%, malignant epithelial lesions (3) $11 \%$ and poorly differentiated carcinomas(2) 7 $\%$. (FIG:3)There were 14 males (52\%) and 13 females(48\%) of 27 Non-small cell lung carcinomas.(FIG:2)

15 cases $(55.5 \%)$ of non-small cell carcinomas showed over expression to EGFR marker and 12 patients were started on the targeted therapy of Gefitinib or Erlonitib. (TABLE:1) Majority of adenocarcinomas -10 cases (67\%), 4 (27\%) of squamous cell carcinoma and 1 (7\%) of malignant epithelial lesion were positive for EGFR marker. There was good response to treatment in nine patients $(75 \%)$ of adenocarcinoma and three $(25 \%)$ of squamous cell carcinoma. All of them were nonsmokers.

There were two interesting cases which presented with distant metastasis and that showed good response to Erlotinib and gefitinib. One was a 51yr old male patient with histopathology report of Infiltrating moderately differentiated adenocarcinoma with desmoplastic stroma.
PET CT \& Whole body scan of the patient showed oligometastasis in brain with extracranial disease, diagnosed as right lung carcinoma with brain secondaries. MRI Brain showed $2.5 \times 2.3 \mathrm{~cm}$ lesion in left occipital lobe with perilesional edema suggestive of metastasis. CECT scan chest showed a small heterogeneous lesion $3 \times 2.8$ $\mathrm{cms}$ in size in the apical segment of right upper lobe with spiculated margins and enlarged perihilar lymph nodes. Genomic alterations showed EGFR positive hot spot mutations. The drug approved was Erlotinib/gefitinib. The treatment given was Erlotinib.

The second interesting case was of $48 \mathrm{yr}$ old female with histopathological report left lung invasive adenocarcinoma lepidic predominant type. Pleural fluid for analysis showed white blood cell count-1350 cells/cumm and Pleural fluid cytology show adenocarcinoma deposits. CT Chest showed consolidation in the left lower lobe, Multiple small nodular lesions in bilateral lung parenchyma-Metastases, collapse of left lower lobe and left pleural effusion .Ultra sound abdomen showed left pleural effusion. FDG PET-CT SCAN of Chest shows a lobular mass lesion of $4.2 \times 3.1 \mathrm{~cm}$ size in left lower lobe and superior segment with adjacent scarring. Patient was diagnosed as Nonsmall cell carcinoma with adrenal and bone metastasis. EGFR Hotspot mutations was positive. Treatment given was gefitinib

\section{Discussion}

Non -small cell carcinomas accounted for majority of lung carcinomas and some of our patients presented with advanced disease at the time of diagnosis in our study. ${ }^{(8)}$ Adenocarcinoma is one of the most common histological subtypes of NSCLC. ${ }^{(9,10)}$ Molecular profiling of tumor samples from patients with NSCLC has identified

\section{TABLE 1}

\begin{tabular}{|c|c|c|c|c|}
\hline & AGE/SEX & CLINICAL DETAILS & HISTOPATHOLOGY DIAGNOSIS & EGFR MARKER \\
\hline 1 & $60 \mathrm{YR} / \mathrm{F}$ & Cough With Expectoration/Positive & Adenocarcinoma & Positive \\
\hline 2 & $62 \mathrm{YR} / \mathrm{F}$ & Cough With Expectoration & Adenocarcinoma & Positive \\
\hline 3 & $48 \mathrm{YR} / \mathrm{F}$ & Cough With Expectoration,Chest Pain & Adenocarcinoma-Lepidic Type & Positive \\
\hline 4 & $51 \mathrm{YR} / \mathrm{M}$ & Cough With Expectoration & Adenocarcinoma & Positive \\
\hline 5 & $53 \mathrm{YR} / \mathrm{F}$ & Cough With Expectoration & Adenocarcinoma & Positive \\
\hline 6 & $71 \mathrm{YR} / \mathrm{M}$ & Cough With Expectoration & Adenocarcinoma & Positive \\
\hline 7 & $64 \mathrm{YR} / \mathrm{M}$ & Cough With Expectoration & Adenocarcinoma & Positive \\
\hline 8 & $58 \mathrm{YR} / \mathrm{F}$ & Cough With Expectoration,Chest Pain & Adenocarcinoma Papillary & Positive \\
\hline 9 & $55 \mathrm{YR} / \mathrm{F}$ & $\begin{array}{c}\text { Cough With Expectoration } \\
\text { Shortness Of Breath }\end{array}$ & Adenocarcinoma & \\
\hline 10 & $73 \mathrm{YR} / \mathrm{M}$ & $\begin{array}{c}\text { Cough With Expectoration } \\
\text { Shortness Of Breath }\end{array}$ & & \\
\hline
\end{tabular}




\begin{tabular}{|c|c|c|c|c|}
\hline & AGE/SEX & CLINICAL DETAILS & HISTOPATHOLOGY DIAGNOSIS & EGFR MARKER \\
\hline 11 & 73 YR/M & Cough With Expectoration & $\begin{array}{c}\text { Adenocarcinoma } \\
\text { Papillary Type }\end{array}$ & Positive \\
\hline 12 & $65 Y R / F$ & Chest Pain ,Cough & Adenocarcinoma & Positive \\
\hline 13 & $39 Y R / F$ & Cough & Adenocarcinoma & Positive \\
\hline 14 & $35 Y R / F$ & Right Side Pleural Effusion & Adenocarcinoma Mucinous & Positive \\
\hline 15 & $45 Y R / M$ & Cough & Adenocarcinoma & Positive \\
\hline
\end{tabular}

\section{percentage}

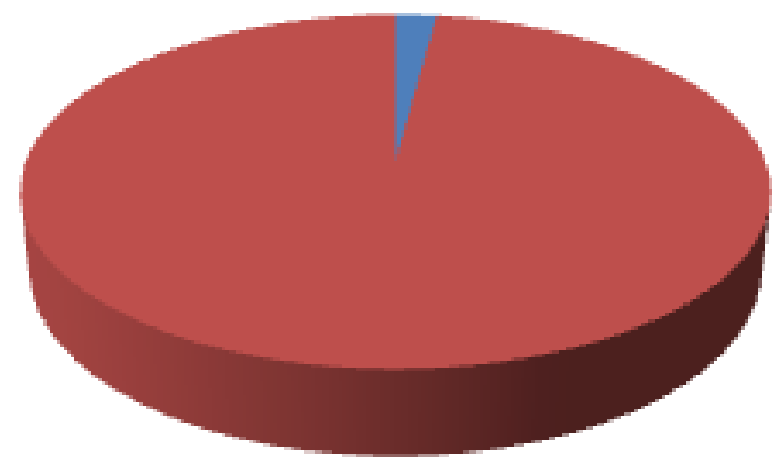

small cell

non small cell

FIg. 1: PERCENTAGE OF SMALL CELL CARCINOMAS/NON SMALL CELL CARCINOMAS.

\section{PERCENTAGE}

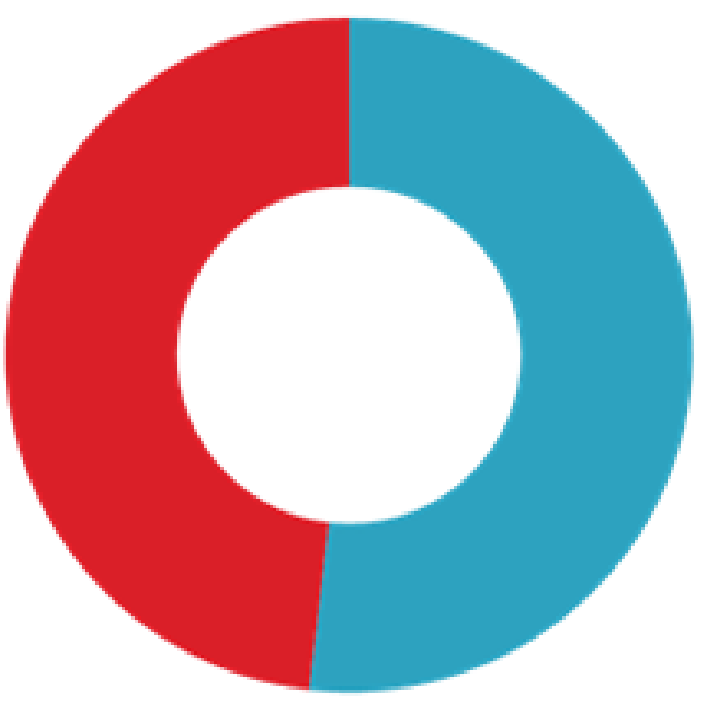

MALE

FEMALE

FIG. 2: PERCENTAGE OF MALE TO FEMALE RATIO. 


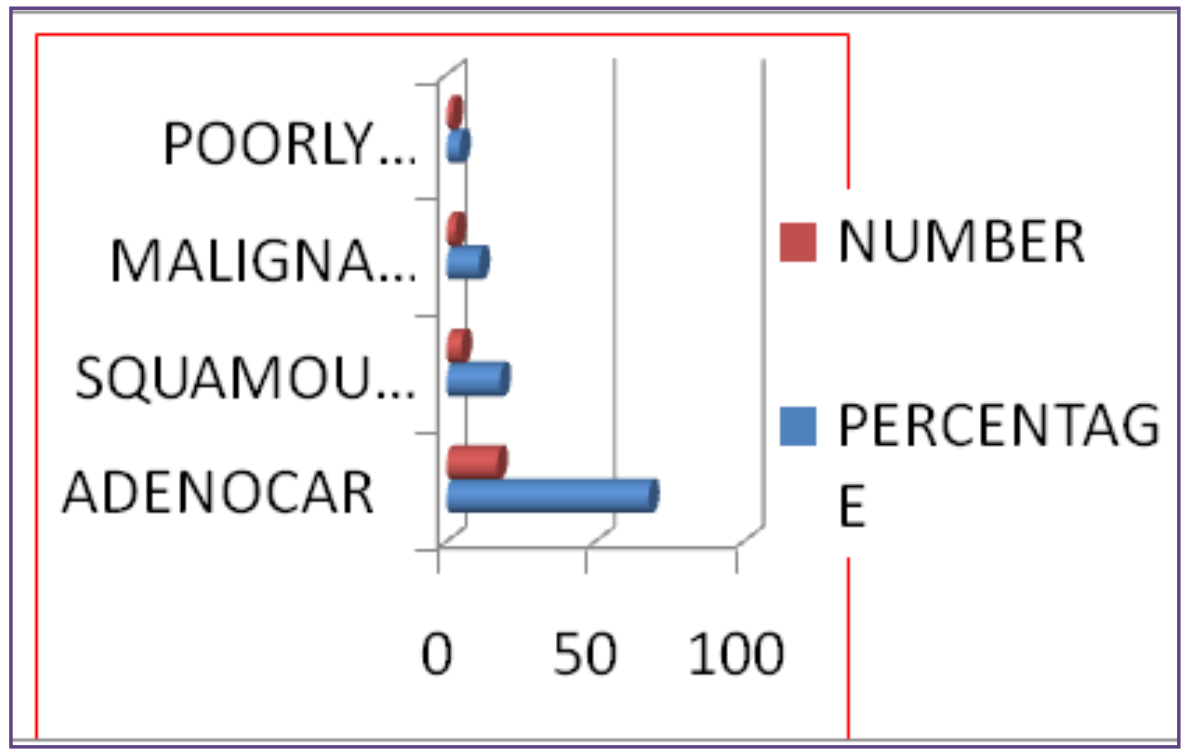

FIG. 3: TYPE OF NON SMALL CELL CARCINOMAS.

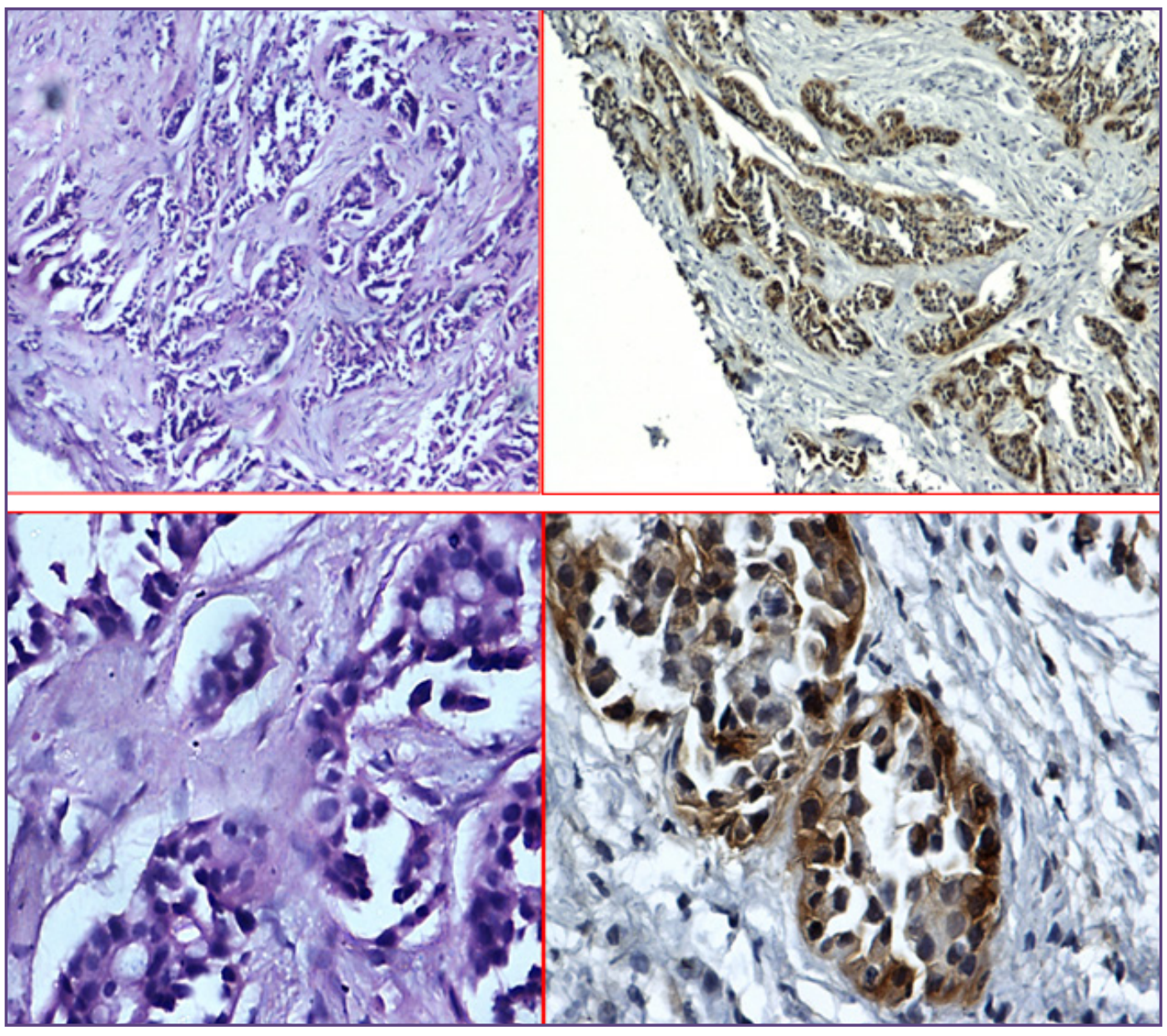

Plate 1: a,b,c,d-Adenocarcinoma H\&E stain 10x,40x,EGFR stain in 10x, 40x 


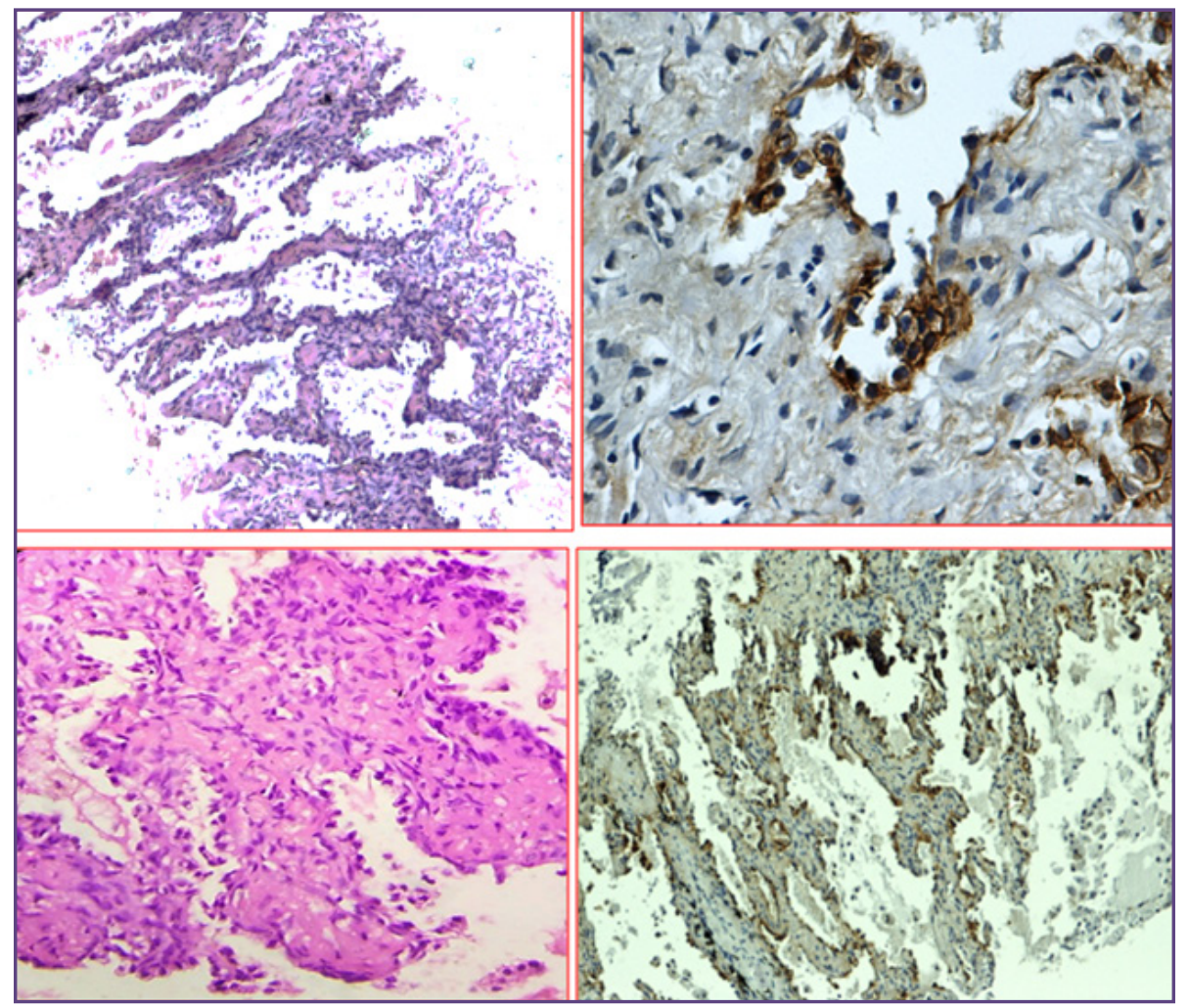

Plate 2:e,f,g,h lepidic adenocarcinoma H\&E 10x,40x, EGFR stain 10 x,40x.

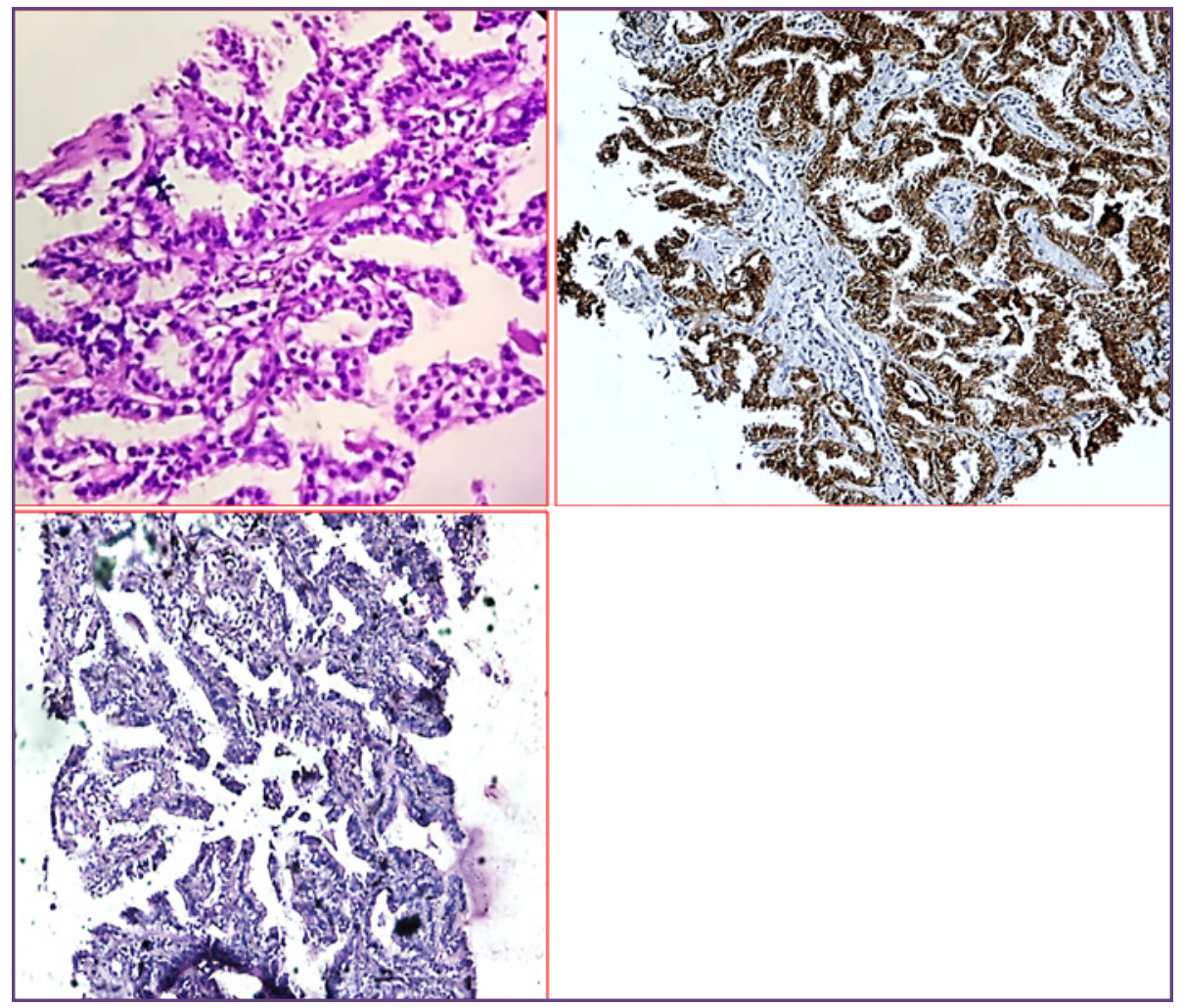

Plate 3:i,j,k Papillary adenocarcinoma H\&E stain 10x,EGFR stain 10 x stain. 


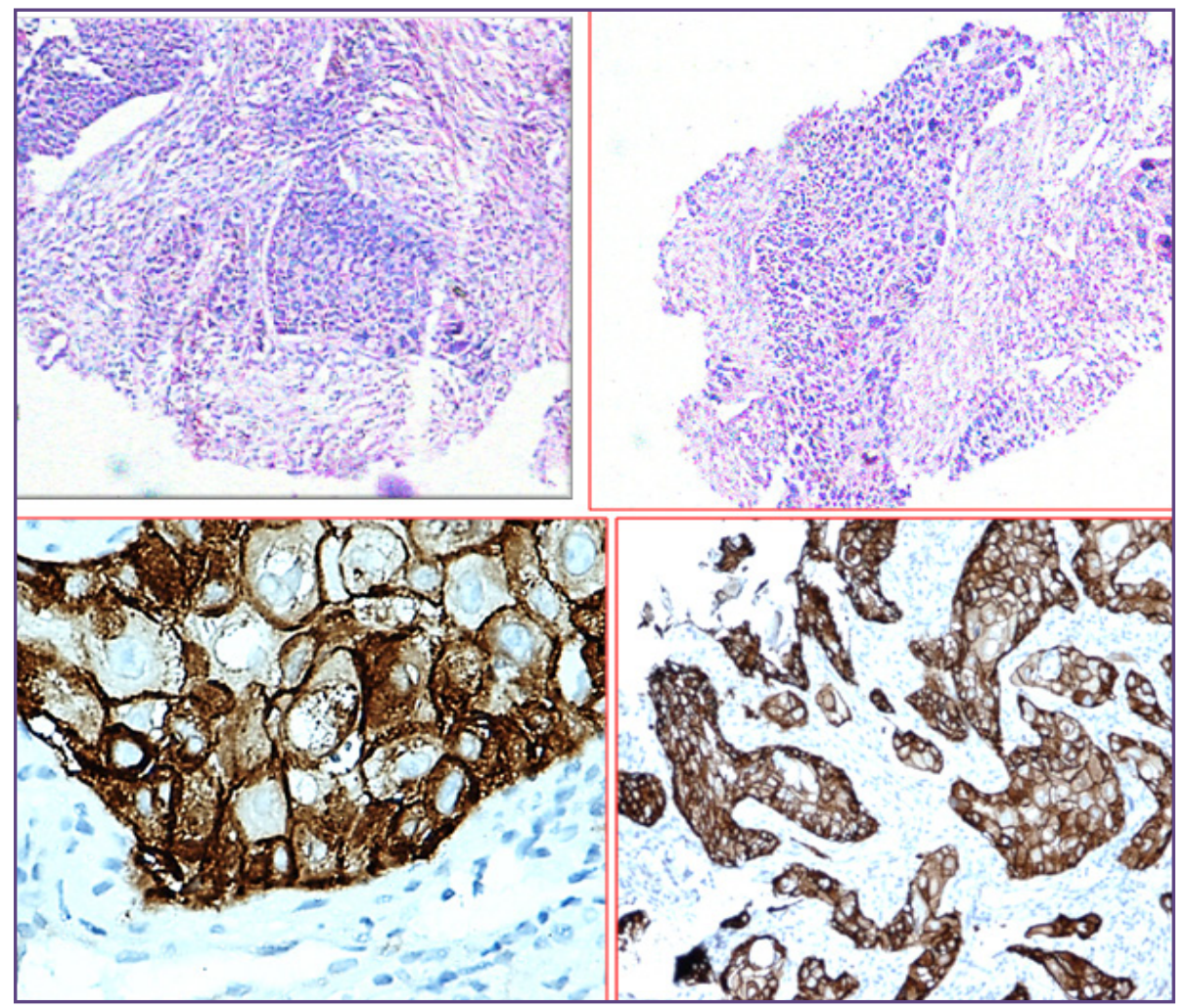

late 4:l,m,n,o :Squamous cell carcinoma 10x,40x,H\&E stain, EGFR stain 40x,10x.

epidermal growth factor receptor mutations in more than $50 \%$ of cases in various studies. ${ }^{(11,12)}$

Three land mark trials in year 2004 showed that lung adenocarcinomas with mutated EGFR had significant responses to gefitinib and erlonitib. ${ }^{(13)}$ Other phase III clinical trials with chemotherapy of erlotinib or gefitinib in NSCLC patients showed a survival improvement for patients with EGFR mutations. ${ }^{(14)}$

Overall response rates to tyrosine kinase inhibitors in adenocarcinomas with mutations in EGFR are in the range of $65-90 \%$ in other studies. ${ }^{(15)} \cdot 75 \%$ of squamous cell and $90 \%$ adenocarcinomas showed response to tyrosine kinase in our study. High response rates to tyrosine kinase inhibitors with EGFR mutations is seen in adenocarcinoma, non- smoker and Japanese patients similar to our study. ${ }^{(13)}$

Tumours with amplified EGFR are more likely to have a significant component of solid growth, association between EGFR amplification. Studies reported certain morphologic characteristics that appear to be associated EGFR mutations have better responses to tyrosine kinase inhibitors. These include adenocarcinoma with a nonmucinous bronchioloalveolar component, hobnail cell type, as well as papillary and micropapillary patterns. ${ }^{(14,15)}$
Papillary and non mucinous bronchioloalveolar type in our study showed good response to chemotherapy.

\section{Conclusions}

Most of the Non-small cell carcinomas of lung have EGFR mutations especially all adenocarcinomas in non-smokers. The clinical outcome of patients could be predicted. There is significant response to chemotherapy especially to TKIs.

\section{Abbreviations}

NSCLC-Non- small cell lung carcinomas, EGFREpidermal growth factor receptor,TKIs- tyrosine kinase inhibitors.

\section{References}

1. Jemal A, Thomas A, Murray $\mathrm{T}$, Thun $\mathrm{M}$. Cancer stastics,2002.;52:23-47.

2. Sasaki H, Endo K, Okuda K, Kawano O, Kitahara N, Tanaka $\mathrm{H}$, et al. Epidermal growth factor receptor gene amplification and gefitinib senstivity in patients with recurrent lung cancer.J Cancer Res Clin Oncol.2008;134:469-77.

3. Schiller JH, Harrington D, Belani CP, Langer C, Sandler A, Krook J, et al.Comparison of four chemotherapy regimens for advanced non-small lung cancer. N Engl J Med.2002;346:92-8.

4. Ohsaki Y, Tanno S, Fujita Y, Toyoshima E, Fujiuchi S, Nishigaki Y, et al. Epidermal growth receptor expression 
correlates with poor prognosis in non-small lung cancer patients with p53 overexpression.Oncol Rep.2000;7:603-

5. Paez JG,Janne PA,LeeJC,Tracy S,Greulich H,et al,2004 EGFR mutations in lung cancer:Correlation with clinical response to gefitinib therapy.Science 304:1497-1500.

6. Lynch TJ, Bell DW, Sordella R, Okimoto RA, et al. Activating mutations in the epidetmal growth factor receptor underlying responsiveness of non small cell cancer to gefitinib. N Engl J med 350;2129-2139

7. Ferlay J, Soerjomataram I, Dikshit R, Eser S, Mathers C, Rebelo M, Parkin DM, Forman D and Bray F. Cancer incidence and mortality worldwide: Sources, methods and major patterns in GLOBOCAN 2012. Int J Cancer 2014; 136: E359-E386.

8. Crinò L, Weder W, van Meerbeeck J and Felip E. Early stage and locally advanced (non-metastatic) non-small-cell lung cancer: ESMO Clinical Practice Guidelines for diagnosis, treatment and follow-up. Ann Oncol 2010; 21 Suppl 5: v103-v115.

9. Youlden DR, Cramb SM and Baade PD. The International Epidemiology of Lung Cancer: geographical distribution and secular trends. J Thorac Oncol 2008; 3: 819-831.

10. Dearden S, Stevens J, Wu YL and Blowers D. Mutation incidence and coincidence in non small-cell lung cancer: meta-analyses by ethnicity and histology (mutMap).

11. Lynch TJ,Bell DW,Sordell R, Gurubhagavatula S,Brannigan $\mathrm{BW}$,et al.Activating mutation in the epiderma growth factor recetor underlying responsiveness of non small cell lung cancer to gefitinib.N Engl J Med .2004;350:2129-39.

12. Paez JG, Janne PA, Lee JC, Tracy S, Greulich H, Gabriel S, et al. EGFR mutations in lung cancer: correlation with clinical response to gefitinib therapy. Science .2004;12:6494-501.

13. Pao w,miller V, Zakowski M, Doherty J, Politi K,et al.(2004) EGF receptor gene mutations are common in lung cancers from never smokers and are associated with sensitivity of tumours to gefitinib nd erlotinib,Proc Natl Acad Sci USA 101:13306-13311

14. Sartori G,Cavazza A,Sgambato A,Marchioni A,Barbieri F,Lucia Longo,et al.EGFR and K-ras mutations along the spectrum of pulmonary epithelial tumors of the lung and elaboration of a combined clinicopathologic and molecular scoring system to predict clinical responsiveness to EGFR inhibitors.Am J clinc pathol.2009;131:478-89

15. Ninomiya $H$,Hiramatsu M,Inamura $K$ et al.Correlation between morphology and EGFR mutations in lung adenocarcinoma;significance of the micropapillary pattern and hobnail cell type.Lung cancer.2009:63;235-40

*Corresponding author:

Dr. GudeliVahini, Flat No: 203, Sree Swetha Enclave Apts, Sree Ramachandra Nagar, Vijayawada,Ap-520008 India

Phone: +91 9949968294

Email: Id-Gudelivahini@Gmail.Com

Financial or other Competing Interests: None. 